\title{
Corporate Governance, Risk Disclosure Practices, and Market Liquidity: Comparative Evidence from the UK and Italy
}

\begin{abstract}
Manuscript Type: Empirical

Research Question/Issue: This paper examines the influence of corporate governance on risk disclosure practices in the UK and Italy and also studies the impact of those practices on market liquidity.

Research Findings/Insights: We find that governance factors principally influence the decisions of UK (Italian) firms over whether to exhibit risk information voluntarily (mandatorily) in their annual report narratives. When we distinguish between firms with strong and weak governance (in terms of board efficiency) in each country, we find that the factors that affect mandatory and voluntary risk disclosure appear to be driven more by strongly governed firms in both countries. Furthermore, in the UK, we find that voluntary and mandatory risk disclosure improves market liquidity significantly by reducing information asymmetry. Moreover, strongly governed firms in the UK tend to provide more meaningful risk information to their investors than weakly governed firms. In Italy, however, we find that strongly rather than weakly governed firms exhibiting risk information voluntarily rather than mandatorily improves market liquidity significantly.
\end{abstract}

Theoretical/Academic Implications: This paper emphasizes the importance of distinguishing between mandatory and voluntary risk disclosure when studying the impact of corporate governance. Our findings differ across strongly and weakly governed firms, in terms of both the factors that influence risk disclosure practices and the exact informativeness of those practices. Furthermore, the findings support the view that disclosing risk information in the narrative sections of annual reports is seen as more credible in the UK than in Italy as such information is likely to be more strongly related to investors' price decisions in the UK than in Italy.

Practitioner/Policy Implications: The results support the current regulatory trend in risk reporting within the UK that emphasizes the importance of directors and encourages rather than mandates risk disclosure. However, the results generally signal a need for further improvements in the Italian context. Our evidence also supports the value of the confidence in the UK governance system, compared to that in Italy, which motivates British firms to provide highly informative risk information more often than Italian firms.

Keywords: Automated Textual Content Analysis; Corporate Governance; Mandatory and Voluntary Risk Disclosure; Usefulness of Risk Disclosure 
This is the peer reviewed version of the following article: Corporate Governance: An International Review, which has been published in final form at http://onlinelibrary.wiley.com/doi/10.1111/corg.12095/abstract]. This article may be used for non-commercial purposes in accordance with Wiley Terms and Conditions for Self-Archiving.

\section{INTRODUCTION}

A significant body of literature demonstrates that the monitoring function of corporate governance significantly influences the propensity for better disclosure (Bushman \& Smith, 2001; Sloan, 2001; Kanagaretnam, Lobo, \& Whalen, 2007; Lim, Matolcsy, \& Chow, 2007; Patelli \& Prencipe, 2007). However, little work has either examined the relationship between risk reporting and corporate governance or studied how risk information influences market liquidity. Studying how corporate governance influences a firm's decision over whether to provide risk information is becoming increasingly important since this information might be useful for investors seeking to reduce information uncertainty by enabling them to estimate an appropriate discount rate to use in their valuation models (e.g., Miihkinen, 2013). Investors might incorporate risk information into their price decisions and thus improve the market liquidity by reducing information asymmetry (e.g., Campbell et al., 2014). Furthermore, Jorgensen and Kirschenheiter (2003) theorize that, if a firm chooses not to disclose risk information, it will have a higher risk premium than firms providing such information, and that premium is likely to be higher in the presence of mandatory risk disclosure than voluntary risk disclosure.

While the relevant UK literature focuses on investigating the impact of either firm characteristics (e.g., Linsley \& Shrives, 2006) or ownership and board characteristics (e.g., Abraham \& Cox, 2007) on aggregated risk disclosure, the relevant Italian literature (e.g., Beretta \& Bozzolan, 2004) studies the impact of certain firm characteristics (i.e., firm size and industry type) on the quantity and quality of aggregated risk disclosure. Rather than relying principally on aggregated risk disclosure, our paper distinguishes between mandatory and voluntary risk disclosure since there is a large body of accounting literature that has emerged from Dye (1986, 1990), such as Gigler and Hemmer (1998), Einhorn (2005), Bagnoli and Watts (2007), and Butler, Kraft, and Weiss (2007), showing that increasing attention is being given to the importance of distinguishing between the two forms of disclosure as each has different underlying incentives. Similarly, 
This is the peer reviewed version of the following article: Corporate Governance: An International Review, which has been published in final form at http://onlinelibrary.wiley.com/doi/10.1111/corg.12095/abstract]. This article may be used for non-commercial purposes in accordance with Wiley Terms and Conditions for Self-Archiving.

Jorgensen and Kirschenheiter (2003) and (2012) theorize as to how mandatory and voluntary risk disclosure impact differently on the market indicators (e.g., market liquidity). The most recent research on the usefulness of risk disclosure suggests that investors incorporate risk information in a way that either affects their perceived risk (Kravet \& Muslu, 2013) or influences decisions on stock prices by improving market liquidity (Miihkinen, 2013; Campbell et al., 2014).

Despite the importance of this distinction that has been highlighted by the above-mentioned theoretical research, empirical research on risk disclosure (e.g., Linsley \& Shrives, 2006; Abraham \& Cox, 2007; Kravet \& Muslu, 2013; Campbell et al., 2014) neither distinguishes mandatory from voluntary risk disclosure in observing the factors that influence that disclosure, observes how corporate governance influences the observed risk disclosure practices over time, nor observes the usefulness of each form of risk disclosure. Additionally and more importantly, prior research does not examine the extent to which observed usefulness (i.e., market liquidity) is conditional on the strength of a firm's corporate governance.

Our paper addresses this gap by studying the following two questions: (1) whether, and if so how, corporate governance characteristics, including board size, non-executive directors, independent non-executive directors, duality of chief executive officer (CEO) and chairman, dividend-yield, concentrated ownership structure, and audit quality, influence mandatory and voluntary corporate risk disclosure in the UK and Italy; (2) the extent to which risk information - either mandatorily and/or voluntarily provided - reduces information asymmetry, by improving the market liquidity between market participants in each country.

In this paper, mandatory risk disclosure is taken to mean risk information that firms exhibit within, or in excess of but still related to, the risk regulations (under International Financial Reporting Standards (IFRS), UK Generally Accepted Accounting Principles (GAAP), and Italian GAAP) that set the minimum requirements. We define voluntary risk disclosure as any other information about risk appearing in the narrative sections of corporate annual reports. Both types of risk disclosure are measured by the number of sentences providing risk information, calculated 
This is the peer reviewed version of the following article: Corporate Governance: An International Review, which has been published in final form at http://onlinelibrary.wiley.com/doi/10.1111/corg.12095/abstract]. This article may be used for non-commercial purposes in accordance with Wiley Terms and Conditions for Self-Archiving.

using automated textual content analysis, which is increasingly being employed in the accounting and finance literature (Li, 2010a, 2010b; Kearney \& Liu, 2014).

Our paper contributes to the prior literature calling for a multi-country study of corporate governance characteristics (e.g., Judge, 2011) as such multi-element measures of corporate governance are an appropriate means of capturing corporate governance effectiveness (e.g., Donnelly \& Mulcahy, 2008). It also contributes to the strand of research calling for the investigation of risk reporting incentives across countries (e.g., Linsley \& Shrives, 2006; Dobler, 2008). The prior literature on cross-national comparison (e.g., Gordon et al., 2013; Moscariello, Skerratt, \& Pizzo, 2014) emphasizes the importance of the underlying differences in cultural, economic and institutional circumstances when investigating factors that influence accounting practices. The extant evidence on cross-country risk reporting (Dobler, Lajili, \& Zéghal, 2011; Elshandidy, Fraser, \& Hussainey, 2014) emphasizes the importance of observing differences in risk reporting practices and investigating the specific factors that explain such variation. Neither Dobler, Lajili, and Zéghal (2011) nor Elshandidy, Fraser, and Hussainey (2014), however, investigate how corporate governance influences risk reporting practices.

The comparison of the influence of corporate governance on risk reporting practices between the UK and Italy is useful since the two are widely seen as representative of contrasting models of European culture and economic and regulatory milieus (Cooke \& Wallace, 1990; Nobes, 1998; Nobes \& Parker, 2010). In particular, these two countries offer unique sets of characteristics and have very different legal origins, the UK having a strong common-law tradition, and Italy one of civil law. Further differences in institutional settings include the large stock market, dispersed corporate ownership, high level of investor protection and strong legal enforcement in the UK compared with a less developed stock market, concentrated ownership, low level of investor rights and weak legal enforcement in Italy (La Porta, Lopez-de-Silanes, Shleifer, \& Vishny, 1998). According to Ball, Kothari, and Ashok (2000), in common-law countries the shareholders alone 
This is the peer reviewed version of the following article: Corporate Governance: An International Review, which has been published in final form at http://onlinelibrary.wiley.com/doi/10.1111/corg.12095/abstract]. This article may be used for non-commercial purposes in accordance with Wiley Terms and Conditions for Self-Archiving.

elect the members of the governing board, payouts are less closely linked to current-period accounting income and disclosure is a more likely solution to the information asymmetry problem.

Our findings suggest that the influence of governance characteristics on risk disclosure practices in UK and Italian firms varies according to the strength of governance within each country, and also that the predominant effects are due to strongly governed firms. Furthermore, our findings support the idea that risk disclosure in the narrative sections of annual reports conveys credible information in the UK, but is less informative and can be characterized more as boilerplate disclosure in Italy. Our results support the UK's current regulatory trend, which emphasizes the importance of directors for stimulating firms to reveal more risk information, and encouraging rather than mandating risk disclosure. However, the results generally signal a need for further improvement in the Italian context. Our evidence also supports the value of the confidence in the UK governance system, compared to that in Italy, which motivates UK firms to provide more highly informative risk information than Italian firms provide.

The following section of the paper sets out the background to our research, synthesizes the prior literature and develops our hypotheses. After that we introduce the methodology. Next, we discuss the empirical results and the robustness checks, and the final section draws conclusions, discusses limitations, and suggests avenues for future research.

\section{BACKGROUND, RELEVANT LITERATURE AND RESEARCH HYPOTHESES}

The corporate governance debate has been addressed to a large extent in the UK, where several reports have shaped the country's approach to corporate governance (Cadbury Report, 1992; ICAEW, 1999b). In 2003, the Financial Reporting Council (FRC), the independent body that regulates corporate governance and reporting, introduced the Combined Code on Corporate Governance on the basis of the concept of "comply or explain". It combined all previous institutional efforts and emphasized the weight of independent non-executive directors, the importance of risk management, and the significance of corporate reporting. 
This is the peer reviewed version of the following article: Corporate Governance: An International Review, which has been published in final form at http://onlinelibrary.wiley.com/doi/10.1111/corg.12095/abstract]. This article may be used for non-commercial purposes in accordance with Wiley Terms and Conditions for Self-Archiving.

The contents of this report have been revised several times (2008, 2010 and 2012). The most recent version, issued in October of 2012, places greater attention on the relationship between corporate governance and corporate reporting, requiring boards to declare that their annual reports and accounts are indeed "fair, balanced and understandable" (FRC, 2012). Furthermore, firms must guarantee that the narrative sections of their annual reports do not, in any way, conflict with their financial statements, and indeed that they constitute an accurate reflection of the company's performance. ${ }^{1}$ Some of the key features of UK best practices can be summarized in the following points: (1) a unitary board with members collectively responsible for leading the company; (2) division of power at the top of the company, with the chairman responsible for running the board and the CEO responsible for running the company; (3) a balance of executive and independent non-executive directors; (4) periodic evaluations of the efficiency of the board and its committees.

In terms of corporate disclosure, the Accounting Standards Board (ASB) in the UK published the original version of the Operating and Financial Review (OFR) in 1993, providing guidance regarding narrative disclosure. Furthermore, in the UK over the last two decades, the Institute of Chartered Accountants in England and Wales (ICAEW) has paid great attention to how UK firms provide information about risk (ICAEW, 1997, 1999a, 2002). All of these documents rely on principles-based recommendations and emphasize the importance of providing risk information voluntarily so as to minimize the cost of capital. More recently, the ICAEW (2011) has suggested ways to improve the risk disclosure in annual reports (e.g., continuously considering investor needs, prioritizing voluntary over mandatory and quantitative over qualitative risk information, and keeping shorter and more effective lists of risks). The main features of the UK approach to risk reporting are (1) that voluntary risk reporting is preferred, on the basis that it improves the quality of accounting information and reduces the cost of capital and (2) that each firm can identify all of its risks individually and accurately rather than providing a list of risk types.

To conclude, the UK's corporate governance emphasizes the board's engagement with the shareholders and compliance with a voluntary code of best practice. This encourages high 
This is the peer reviewed version of the following article: Corporate Governance: An International Review, which has been published in final form at http://onlinelibrary.wiley.com/doi/10.1111/corg.12095/abstract]. This article may be used for non-commercial purposes in accordance with Wiley Terms and Conditions for Self-Archiving.

standards of corporate governance behavior, and assumes a strong relationship between corporate governance factors and risk disclosure.

In Italy, the debate and regulation on corporate governance have emerged more recently. Italy has adopted the Code of Self-Regulation, prepared by the Corporate Governance Committee of Borsa Italiana SpA, first issued in 1999 and amended in 2002, 2006, 2010, 2011 and 2014, which is based on the "comply or explain" principle. The changes in the Italian regulation highlight the importance of board structure and the independent directors as a means to overcome Italian market weaknesses such as the markedly concentrated ownership and the trend for large owners to expropriate minority shareholders.

The link between corporate governance and corporate reporting is also affirmed in the Italian code, with specific requirements regarding disclosure in the governance recommendations. Moreover, in the latest version of the report, a lot of attention was placed on risk disclosure, with a specific appendix included to discuss the importance of risk management disclosure. This emphasis on risk disclosure stems from a consultative document that was issued in 2008 by the Council of Italian Chartered Accountants (IRDCEC, 2008) to assist entities with implementing the new requirements for management reporting that emerged after the introduction and implementation of Directive 2001/65/EC and the subsequent changes in the Civil Code of Italy (Legislative Decree No. 32/2007 that modified Article 2428 of the Civil Code). ${ }^{2}$ The new regulation, in fact, forces firms to include a description of their risks and uncertainties in the Management Discussion and Analysis (MD\&A) section of their annual report. In other words, managers have to explain in detail all of the risks faced by their company during the past year, and how they have managed these risks, in their annual reports.

To sum up, despite these normative efforts, the Italian corporate governance regime exhibits low legal protection for investors and poor legal enforcement, underdeveloped equity markets and a very high ownership concentration.

\section{Relevant Literature and Research Hypotheses}


This is the peer reviewed version of the following article: Corporate Governance: An International Review, which has been published in final form at http://onlinelibrary.wiley.com/doi/10.1111/corg.12095/abstract]. This article may be used for non-commercial purposes in accordance with Wiley Terms and Conditions for Self-Archiving.

It has been argued that corporate disclosure can be linked to a firm's corporate governance structure through its inputs and/or its outputs. Specifically, the monitoring role of corporate governance is not only achieved through numeric accounting, but also involves corporate disclosure. Additionally, it is the governance structure itself that encourages a manager to adopt the best disclosure policy (Core, 2001; Karamanou \& Vafeas, 2005). Further, Sloan (2001) argues that corporate disclosure is one of the corporate governance mechanisms employed for the purposes of external management oversight.

The above studies have documented, consistent with their theoretical arguments, a relationship between corporate governance and voluntary disclosure based on the latter's role as a control mechanism for agency problems. The effects of corporate governance on reporting practice mitigate information asymmetry and improve the stewardship function. Accurate risk information, as an external control mechanism that reduces agency costs, is fundamental for shareholders, analysts and investors, enabling them to assess a company's risk profile, estimate its market value and make accurate investment decisions (Rajgopal, 1999; Jorion, 2002; Kravet \& Muslu, 2013; Miihkinen, 2013; Campbell et al., 2014).

Based on the emerging and relevant prior literature on corporate governance, corporate disclosure in general, and risk disclosure in particular, we will now introduce several corporate governance mechanisms and their possible effects on risk disclosure practices, and then we will look at the influence of those practices on market liquidity. Based on this, we will formulate this paper's hypotheses.

\section{Risk Disclosure Practices and Corporate Governance}

Board size. It would appear from the significant amount of extant research that is available that, in cases where the board monitors the management more effectively, the quality and regularity of the information made known to the investors by the management does improve (Ajinkya, 
This is the peer reviewed version of the following article: Corporate Governance: An International Review, which has been published in final form at http://onlinelibrary.wiley.com/doi/10.1111/corg.12095/abstract]. This article may be used for non-commercial purposes in accordance with Wiley Terms and Conditions for Self-Archiving.

Bhojraj, \& Sengupta, 2005; Karamanou \& Vafeas, 2005). Verrecchia (2001) demonstrates that greater disclosure will lessen the need for research into private information. From this argument, it would appear that information asymmetry, generally speaking, is not as high in those firms that have more effective boards.

It has been argued that board size is a key element in determining the effectiveness of a board of directors. On the one hand, Yermack (1996) argues that large boards are likely to be less effective than smaller boards at reducing agency costs. On the other hand, in firms with a higher ownership concentration, and where insider shareholders are strongly represented on the boards, larger boards do not necessarily signal a less effective governance structure (Di Pietra, Grambovas, Raonic, \& Riccaboni, 2008). This literature supports the view that larger boards may be more effective in reducing actual agency costs by aligning any conflicts of interest that may occur between insiders and outsiders.

Recent research has questioned the extent to which larger boards can affect levels of disclosure (Di Pietra, Grambovas, Raonic, \& Riccaboni, 2008; Lynck, Netter, \& Yang, 2008). Empirical research, mainly based on US data, supports this view. For instance, Hoitash, Hoitash, and Bedard (2009) examine the impact of board size on the level of voluntary disclosure, and Yermack (1996) investigates the effect of board size on firm value. In their analysis of the Alternative Investment Market (AIM) in the UK, Mallin and Ow-Yong (2012) found voluntary disclosure to be positively related to board size. In the Italian context, Allegrini and Greco (2013) obtained the same result. Lynck, Netter, and Yang (2008) further maintain that insider shareholder representation on boards is more typical of smaller and less independent boards, a finding that ties in with the theory that managerial ownership and board monitoring can substitute for governing mechanisms.

Based on the above discussion, we hypothesize that board size will be positively associated with the level of risk disclosure practices, as formulated in the following hypothesis: 
This is the peer reviewed version of the following article: Corporate Governance: An International Review, which has been published in final form at http://onlinelibrary.wiley.com/doi/10.1111/corg.12095/abstract]. This article may be used for non-commercial purposes in accordance with Wiley Terms and Conditions for Self-Archiving.

Hypothesis 1: Firms with large boards of directors, in the UK and Italy, tend to exhibit significantly high levels of risk disclosure, in mandatory terms and/ or when offered voluntarily.

Board independence. Agency theory argues that independent directors are likely to mitigate agency conflicts between insiders (managers) and outsiders (shareholders), as these directors will have no ties with the managers or representative shareholders and should be able to offer truly objective opinions that benefit the company (Patelli \& Prencipe, 2007). Independent directors may also have high incentives to increase the levels of voluntary disclosure and thus signal their lack of complicity with the insiders (leaders, management and strong ownership) and their own ability to improve their company's market value.

Prior research (Ajinkya, Bhojraj, \& Sengupta, 2005; Karamanou \& Vafeas, 2005) has examined in detail the influence of board structure on voluntary disclosure levels. These studies find that board composition, measured by the percentage of independent directors on a board, and the quality of the board of directors overall are likely to influence the amount of corporate information managers can manage and disclose. These studies further argue for a positive relationship between board composition and the level of corporate disclosure. Early evidence provided by Forker (1992) and based on 82 UK listed firms found a positive link between financial disclosure and the proportion of independent directors.

Consistent with that evidence, Donnelly and Mulcahy (2008) demonstrate that voluntary disclosure increases with the number of non-executive directors on a board. Gul and Leung (2004) further find that independent directors are likely to significantly increase firms' abilities to exhibit more voluntary information than other firms. More recently, Romano and Guerrini (2012) have found a positive correlation between mandatory disclosure and independent directors in a sample of Italian listed companies over the period 2002-2010.

We follow the prior literature (e.g., Gul \& Leung, 2004; Abraham \& Cox, 2007; Patelli \& Prencipe, 2007), which distinguishes between non-executive directors with business or ownership ties to the company and/or relationships with management (dependent non-executive directors) 
This is the peer reviewed version of the following article: Corporate Governance: An International Review, which has been published in final form at http://onlinelibrary.wiley.com/doi/10.1111/corg.12095/abstract]. This article may be used for non-commercial purposes in accordance with Wiley Terms and Conditions for Self-Archiving.

and those without (independent non-executive directors). Therefore, we adopt the legal definition, which states (Gul \& Leung, 2004; Patelli \& Prencipe, 2007) that independent non-executives should (1) have no allegiance to a particular shareholder or group of shareholders; (2) not obtain membership of the board to protect the interests of a third party; (3) not be connected to management; (4) not be current or former executives of the company; (5) not have financial or other interests in the business of the company or its subsidiaries. Based on the above discussion of the relevant theory and literature, we expect that the presence of non-executive and independent non-executive directors on a board will be positively related to the level of risk disclosure practices. The following two hypotheses are thus formulated:

Hypothesis 2a: Firms with a high proportion of non-executive directors, in the UK and Italy, tend to exbibit significantly high levels of risk disclosure, in mandatory terms and/ or when offered voluntarily.

Hypothesis 2b: Firms with a bigh proportion of independent non-executive directors, in the UK and Italy, tend to exhibit significantly bigh levels of risk disclosure, in mandatory terms and/or when offered voluntarily.

CEO duality. CEO duality refers to the situation in which there is no separation between decision control and decision management (Fama \& Jensen, 1983). It is argued that firms with CEO duality are likely to offer poorer disclosure (Finkelstein \& D’Aveni, 1994).

Prior research on corporate governance offers mixed results with regard to the association between CEO duality and disclosure. For instance, Cheng and Courtenay's (2006) results do not support a significant impact of CEO duality on voluntary disclosure, while those of Li, Pike, and Haniffa (2008) do.

Worrell, Nemec, and Davidson (1997) provide evidence that the stock market tends to react negatively to announcements of CEO duality, which would seem to support the claim that CEO duality has a negative effect on a board's monitoring role. Consistent with this point, Gul and Leung (2004) find that CEO duality is likely to reduce the level of voluntary disclosure. Similarly, Cerbioni and Parbonetti (2007) find evidence that a concentration of power is negatively associated with both the quantity and the quality of the voluntary disclosure of intellectual capital. More recent research within the Italian and UK contexts supports the negative impact of concentrating 
This is the peer reviewed version of the following article: Corporate Governance: An International Review, which has been published in final form at http://onlinelibrary.wiley.com/doi/10.1111/corg.12095/abstract]. This article may be used for non-commercial purposes in accordance with Wiley Terms and Conditions for Self-Archiving.

the power of the chairman and $\mathrm{CEO}$ in one person on the voluntary disclosure of general or forward-looking information (Allegrini \& Greco, 2013; Wang \& Hussainey, 2013). Given these considerations, we formulate the following hypothesis:

Hypothesis 3: Firms with CEO duality, in the UK and Italy, tend to exhibit significantly low levels of risk disclosure, whether in mandatory terms or offered voluntarily.

Dividend policy. According to agency theory, dividends may have a mitigating effect on agency costs through the distribution of free cash flow that a firm's management might otherwise spend on unprofitable projects (Jensen, 1986). Fluck (1998) acknowledges that dividend policies are a way of dealing with agency problems that relate to corporate insiders and shareholders.

Dividend payments may be viewed as a sort of risk premium that is distributed to the shareholders. In addition, investors who receive dividends may have less interest in information concerning the risks a firm is addressing. Thus, paying dividends may make up for reduced risk disclosure. Farinha (2003) argues that managers may pay dividends to avoid disciplinary action by shareholders, and he finds a positive link between company compliance with the Cadbury report's "best practices" for governance, and dividend payouts in the UK.

Similarly, the prior literature on corporate disclosure within the UK has found that firms with lower dividend yields are likely to provide significantly higher levels of voluntary disclosure (i.e., forward-looking information) than other firms (e.g., Hussainey \& Walker, 2009). The empirical research (e.g., Mancinelli \& Ozkan, 2006) shows that the payouts of Italian companies are inversely proportionate to the voting rights of the largest company shareholder.

The fact that firms have a choice of dividend policy suggests that high dividend payments are associated with less riskiness and less information asymmetry for firms. The higher are the dividends, the better will be the corporate governance practices of the company, thus reflecting the power of the minority shareholders. This discussion leads us to formulate the following hypothesis:

Hypothesis 4: Firms with high payout dividends, in the UK and Italy, tend to exhibit significantly low levels of risk disclosure, in mandatory terms and/or when offered voluntarily. 
This is the peer reviewed version of the following article: Corporate Governance: An International Review, which has been published in final form at http://onlinelibrary.wiley.com/doi/10.1111/corg.12095/abstract]. This article may be used for non-commercial purposes in accordance with Wiley Terms and Conditions for Self-Archiving.

Concentrated ownership structure. The fact that ownership and control are separate in private and public corporations leads to a problem between principal and agent, which can result in a less than optimal use of capital (Shleifer \& Vishny, 1997). Wherever ownership is widely dispersed, the individual shareholders have practically no incentive to monitor the management. The marginal cost of such monitoring is often greater than the marginal benefit of the better performance that may result from it.

Concentrated ownership may bring about better management control since the volume of the ownership stake and the incentive to monitor are positively linked. Better management control is likely to improve firm performance and, thus, provide benefits to the minority shareholders. However, there may also be costs for the minority shareholders, considering that the controlling owners could attempt to expropriate value from them. In a cross-country analysis, Faccio and Lang (2002) show that Italy has one of the lowest percentages of firms with dispersed ownership in Europe. Meanwhile, in a sample of 450 UK companies, Brammer and Pavelin (2006) find that firms showing dispersed ownership features are far more likely to disclose voluntary information than other firms. This knowledge leads us to formulate the following hypothesis:

Hypothesis 5: Firms with highly concentrated ownership, in the UK and Italy, tend to exbibit significantly low levels of risk disclosure, in mandatory terms and/ or when offered voluntarily.

Audit quality. Based on agency theory, when agency costs are high, firms are likely to use corporate governance mechanisms and voluntary disclosure to diminish those costs. External audit firms can have a marked effect on the degree of voluntary information disclosed in company annual reports (Barako, Hancock, \& Izan, 2006). Financial statements audited by a reputable independent auditor may also augment the level of investor confidence, both in the firm and in its annual report. Frankel, Johnson, and Nelson (2002) show that the monitoring offered by an independent and high-quality external auditor reduces the management's ability to engage in earnings management activities. In a comparative study of Dutch and UK companies, Camfferman 
This is the peer reviewed version of the following article: Corporate Governance: An International Review, which has been published in final form at http://onlinelibrary.wiley.com/doi/10.1111/corg.12095/abstract]. This article may be used for non-commercial purposes in accordance with Wiley Terms and Conditions for Self-Archiving.

and Cooke (2002) find a positive association in the UK between voluntary disclosure and those firms audited by big auditing firms. This knowledge leads us to formulate the following hypothesis:

Hypothesis 6: Firms with high audit quality, in the UK and Italy, tend to exbibit significantly high levels of risk disclosure, in mandatory terms and/or when offered voluntarily.

\section{Risk Disclosure Practices and Market Liquidity}

The prior literature on general disclosure (e.g., Diamond \& Verrecchia, 1991) argues that increased disclosure reduces information asymmetry through two effects. First, increasing the accounting information provided to the public makes private information difficult or costly to attain. Fewer investors, consequently, will be able to obtain private information, which reduces the possibility of trading with a better-informed investor. Second, more disclosure reduces the uncertainty that investors might have regarding their investments.

Collectively, both effects increase market liquidity by reducing the probability of uninformed investors raising prices to protect themselves against the possibility of making losses due to trading with informed investors. The bid-ask spread is a mechanism for the price of protection when buying or selling shares on the market (Leuz \& Verrecchia, 2000). Prior research supports these arguments, finding that high levels of voluntary disclosure significantly improve market liquidity through a reduction in information asymmetry.

Prior risk disclosure research in the US context directly measures the information content of risk disclosure on the 10-K form of the SEC filings. For example, Campbell et al. (2014) find that the quantity (the length) of the risk factor (item 1.A, a compulsory requirement of the SEC since 2005) is positively linked to a reduction in information asymmetry, which increases market liquidity (as proxied by the bid-ask spread). Consistent with these findings, Miihkinen (2013) finds that, in the highly regulated Finnish context, risk disclosure is negatively associated with information asymmetry. Neither Miihkinen (2013) nor Campbell et al. (2014), however, examines whether mandatory and/or voluntary risk disclosure conveys meaningful information, nor the extent to which such associations might differ between strongly and weakly governed firms. 
This is the peer reviewed version of the following article: Corporate Governance: An International Review, which has been published in final form at http://onlinelibrary.wiley.com/doi/10.1111/corg.12095/abstract]. This article may be used for non-commercial purposes in accordance with Wiley Terms and Conditions for Self-Archiving.

Arguably, firms with strong boards of directors have greater power to reveal informative details about firm risk to investors to reduce information asymmetry. Based on the above arguments, we formulate the following hypothesis:

Hypothesis 7: The expected negative association between the amount of risk disclosure and information asymmetry, among firms in the UK and Italy, is likely to be more pronounced among strongly than weakly governed firms.

\section{METHODOLOGY}

\section{Sample Selection and Data Collection}

This paper analyzes the impact of corporate governance on mandatory and voluntary risk disclosure for a sample of non-financial firms in the UK and Italy over a period of five years from June 2005 to June 2010. The paper also studies the impact of those practices on market liquidity. Following the prior literature (e.g., Marshall \& Weetman, 2007), we excluded financial firms due to their special nature. We also excluded cross-listed firms to avoid cross-regulation effects (e.g., Marshall \& Weetman, 2002; Abraham \& Cox, 2007). The starting point of 2005 is the year in which the IFRS became mandatory in both countries, and the reason for ending the study in 2010 is based on data availability. As this study relies on the texts of annual reports, we excluded those annual reports that could not be converted into text files in order to ensure their readability by QSR(6). Our final sample consisted of 1,890 firm-year observations (290 British non-financial firms with 1,450 firm-year observations and 88 Italian non-financial firms with 440 firm-year observations). We utilized annual reports, since external investors still perceive them to be a major and credible source of data (e.g., Beattie, McInnes, \& Fearnley, 2004; Donnelly \& Mulcahy, 2008).

\section{Variable Measurement}

Mandatory and voluntary risk disclosure. We used automated textual content analysis (e.g., Li, 2010a, 2010b; Kearney \& Liu, 2014) to capture risk disclosure scores, using QSR(6). Based on the prior literature (Elshandidy, Fraser, \& Hussainey, 2013), and by reading and examining 30 randomly selected annual reports from each country, we generated a risk word list including the 
This is the peer reviewed version of the following article: Corporate Governance: An International Review, which has been published in final form at http://onlinelibrary.wiley.com/doi/10.1111/corg.12095/abstract]. This article may be used for non-commercial purposes in accordance with Wiley Terms and Conditions for Self-Archiving.

following words: against, catastrophe (catastrophic), challenge (challenges), chance (chances), decline (declined), decrease (decreased), differ*, diversify*, fail (failure), fluctuate*, gain (gains), high*, increase (increased), less, loss*, low*, peak (peaked), probable*, reverse (reversed), risk*, significant*, shortage, threat, unable, uncertain (uncertainty, uncertainties) and viable. * indicates that we also included derivatives of the original word. The words were translated into Italian to generate the risk disclosure scores for the Italian firms.

We generated aggregated risk disclosure scores for each country by counting the frequencies of sentences containing at least one of these risk words. Seminal research (e.g., Bowman, 1984) recommends using sentences rather than words as the coding unit in content analysis due to their greater reliability, since individual words may not indicate anything in particular. More importantly, and consistent with Kravet and Muslu (2013), using the sentence as the basis of coding avoids the problem of double-counting, as each risk sentence is scored once even if it contains more than one word indicating risk.

In order to extract mandatory risk scores from the aggregated risk scores, we analyzed the risk regulations in both countries. We found that UK and Italian listed firms have had to follow the IFRS since 2005, and that the IFRS concur with both the UK and Italian GAAP regarding risk reporting. Despite the fact that neither the UK ASB, the Italian Accounting Committee (Organismo Italiano di Contabilità, OIC) nor the International Accounting Standards Board (IASB) publishes an accounting standard on risk reporting, either exclusively or comprehensively, there are, nonetheless, several accounting standards that do require companies to provide some specific information about their risks. ${ }^{3}$ To accomplish our textual search, we synthesized those accounting standards, issued by ASB, IASB, and OIC, into six principal themes as follows: contingencies (FRS 12; IAS 37; OIC 19); segment reporting (SSAP 25; IAS 14 and IFRS 8; OIC 1), foreign exchange (FRS 23; IAS 21; OIC 26); the substance of transactions or investments (FRS 5; IAS 16; OIC 16); related party disclosures (FRS 8; IAS 24; Appendix of OIC 12); derivatives or financial instruments and fair value (FRS 13, 25, 26, 29; IAS 32, 39 and IFRS 7; OIC 3, 15, 20). 
This is the peer reviewed version of the following article: Corporate Governance: An International Review, which has been published in final form at http://onlinelibrary.wiley.com/doi/10.1111/corg.12095/abstract]. This article may be used for non-commercial purposes in accordance with Wiley Terms and Conditions for Self-Archiving.

We therefore identified our final mandated word list as follows: contingencies, derivatives and/or financial instruments, fair value(s), foreign currency, investments and segment(s). ${ }^{4}$

Mandatory risk disclosure was then calculated by counting the number of sentences that both belonged to the aggregated risk disclosure set and also contained at least one word that was related to the final mandated word list. Voluntary risk disclosure was the number of sentences that belonged to the aggregated risk disclosure set after excluding these mandatory risk disclosure sentences. In other words, the voluntary risk score was equal to the aggregated risk score minus the mandatory risk score. Appendix 1 offers examples of extracted sentences captured by QSR(6) for each type of disclosure.

To check our risk disclosure scores' validity and reliability, we compared manual and automated textual content analysis (Wang \& Hussainey, 2013) scores to examine two issues. First, we examined whether there was consistency between the two methods by calculating the internal consistency using Cronbach's alpha and then confirming such consistency by looking at whether both methods conveyed the same content using the correlation between the manual and automated scores for voluntary and mandatory risk disclosure. Second, we tested whether there were significant differences between these two methods in capturing the mandatory and voluntary risk disclosure scores using the Mann-Whitney test. To that end, we randomly selected 29 and 27 firms from the UK and Italy, respectively, allocated into five categories reflecting risk disclosure level, ranging from the lowest (from the $5 \%$ to the $25 \%$ quantile) to the highest (from the $95 \%$ to the $100 \%$ quantile) disclosure scores. For those firms, we calculated the mandatory and voluntary risk disclosure scores manually and compared them to the scores obtained from QSR(6). ${ }^{5}$

Our results based on Cronbach's alpha, which provides a statistical measure of how well a dataset captures a particular underlying construct, confirmed a high consistency between the manual and automated methods in identifying and scoring risk disclosure. Specifically, these results showed $91 \%$ and $94.7 \%$ consistency between the manual and automated coding for the mandatory and voluntary risk disclosure scores, respectively. Within each country, we found very high 
This is the peer reviewed version of the following article: Corporate Governance: An International Review, which has been published in final form at http://onlinelibrary.wiley.com/doi/10.1111/corg.12095/abstract]. This article may be used for non-commercial purposes in accordance with Wiley Terms and Conditions for Self-Archiving.

consistency between the two methods. In these analyses, the consistencies between the two methods were $94 \%(98.4 \%)$ and $87.6 \%(82.2 \%)$ for mandatory (voluntary) risk scores in the UK and Italy, respectively. All these values were acceptable when compared with the generally accepted social science measure of $70 \%$ (Botosan, 1997). Consistent with our previous findings, we found the correlation coefficient to be $0.915(0.825)$ between the automated and the manual method, for calculating the mandatory risk disclosures in the UK (Italy), at a p-value of 0.000 . For voluntary risk disclosure, the figure was $0.986(0.706)$ in the UK (Italy). Lastly, our results, based on the Mann-Whitney test, confirmed the null hypothesis that the distribution of mandatory (or voluntary) risk disclosure was the same across both manual and automated methods. We therefore concluded that our computed disclosure scores were both reliable and valid.

Market liquidity. Consistent with Leuz and Verrecchia (2000) and Miihkinen (2013), we measured market liquidity or information asymmetry by calculating the average of the relative spreads over a three-month period, from the beginning of May to the end of July. We chose this period to ensure that the financial reporting would be publicly available to users, since financial reporting is required to be available by the beginning of May, four months after fiscal year end (i.e., end of December). We calculated the three-month mean of the relative spreads by dividing the difference between the daily ask and bid prices by the average of the daily ask and bid prices.

Corporate governance. Corporate governance variables were collected manually and included so that we could study their impact on risk disclosure. These variables were as follows: board size, measured by the log of the total number of board directors; non-executive directors, the proportion of non-executive directors, relative to the board size; independent non-executive directors, the proportion of independent non-executive directors, relative to the board size; the dividend yield, as the log of the ratio of the most recent full-year dividends to the current share price; CEO duality, measured as a dummy variable set to 1 if the CEO is also chairman of the board of directors and 0 otherwise; concentrated ownership structure, captured by closely held shares, proxied by the log of the percentage of shares owned by firm insiders (e.g., shares held by 
This is the peer reviewed version of the following article: Corporate Governance: An International Review, which has been published in final form at http://onlinelibrary.wiley.com/doi/10.1111/corg.12095/abstract]. This article may be used for non-commercial purposes in accordance with Wiley Terms and Conditions for Self-Archiving.

officers, directors and their families, or by any individual holding $5 \%$ or more of the outstanding shares); audit quality, a dichotomous variable set to 1 if the external auditor is one of the "big four" and 0 otherwise.

Control variables. We controlled for a number of different possible determinants selected on the basis of prior research. Those determinants broadly reflect firm-specific incentives. Specifically, we controlled for firm size since the signaling theory suggests that larger firms have larger analyst followings and hence are better able to distribute firm information. Further, these firms are likely to be able to provide this information to the users of annual report narratives at a reasonable cost. The prior risk reporting literature either finds no significant impact of firm size on the quantity and/or quality of risk disclosure, as in Beretta and Bozzolan (2004), finds a negative relation as in Campbell et al. (2014), or finds a positive impact on aggregated disclosure, as in Linsley and Shrives (2006) and Abraham and Cox (2007). Firm size was measured as the log of total assets. We also accounted for firm growth, as an extensive and credible disclosure policy will serve to improve a firm's ability to fund its growth opportunities. High-growth firms are likely to have greater information asymmetry and higher agency costs (Gaver \& Gaver, 1993). In the context of risk reporting, Elshandidy, Fraser, and Hussainey (2013) hypothesize such a positive association but their findings do not support such a prediction. We measured firm growth as the $\log$ of the ratio of the difference between earnings in the years $t_{1}$ and $t_{0}$ to earnings in the year $t_{0}$.

We also controlled for firm profitability and liquidity. Arguably, the managers of firms with higher returns are more likely than other firms to be highly motivated to signal this information to the market (e.g., Chavent et al., 2006). Firm profitability was measured as the log of the return on equity (ROE). Eng and Mak (2003) argue that companies with higher liquidity are likely to be more transparent in their annual reports and on their websites regarding their corporate governance mechanisms. Marshall and Weetman (2007) find that highly liquid US and UK firms are likely to provide higher levels of information concerning foreign exchange risk management. Firm liquidity 
This is the peer reviewed version of the following article: Corporate Governance: An International Review, which has been published in final form at http://onlinelibrary.wiley.com/doi/10.1111/corg.12095/abstract]. This article may be used for non-commercial purposes in accordance with Wiley Terms and Conditions for Self-Archiving.

was thus measured in this study as the log of the ratio of total current assets to total current liabilities.

We also controlled for firm risk and capital structure. Relatively high-risk firms may disclose more risk information to meet their investors' requirements for more information about risk drivers and the methods that the firms use to evaluate and address their risks. Elshandidy, Fraser, and Hussainey (2013) find, in line with Deumes (2008), that risky firms have higher incentives than less risky firms to exhibit risk information voluntarily to avoid misinterpretations by market participants. We measured firm risk by the beta, which is the covariance of a firm's market return relative to a market index. This calculation was based on between 23 and 35 consecutive monthend firm prices, relative to the market returns of the FTSE All Share in the UK, and the FTSE MIB in Italy. While some studies (e.g., Deumes \& Knechel, 2008; Elshandidy, Fraser, \& Hussainey, 2013) have found that firm leverage positively and significantly influences the level of risk information firms provide in their narratives, some other studies (Dobler, Lajili, \& Zéghal, 2011; Miihkinen, 2012) have reported a negative association between leverage and risk disclosure. Firm capital structure was measured by the log of leverage, proxied by the ratio of total debt to total equity.

Following Campbell et al. (2014), we also controlled for book-to-market value (BTM), which can affect a firm's stock returns either positively or negatively depending on how market participants associate a high or low BTM with a firm's future growth. BTM is measured as the book value of equity divided by the market value of equity. Lastly, and consistent with Leuz and Verrecchia (2000), we controlled for share price volatility, which we expected to be positively associated with the relative spread, and the trading volume, which we expected to be negatively associated with the relative spread. The share price volatility was measured by the standard deviation of daily stock prices (adjusted). The trading volume was measured by dividing the daily trading volume, that is, the number of shares traded on day $i$, by the number of outstanding shares. 
This is the peer reviewed version of the following article: Corporate Governance: An International Review, which has been published in final form at http://onlinelibrary.wiley.com/doi/10.1111/corg.12095/abstract]. This article may be used for non-commercial purposes in accordance with Wiley Terms and Conditions for Self-Archiving.

Table 1 shows descriptive statistics for the UK and Italian firms. The $t$-test results suggest that there are significant differences in the risk disclosure, corporate governance and market indicator variables between the two countries. The differences for risk disclosure indicate that UK firms tend, on average, to exhibit more (less) risk information voluntarily (mandatorily) than Italian firms do. When we consider the differences between disclosure types within each country, our results confirm that UK (Italian) firms tend to provide, on average, 61\% (10\%) more voluntary than mandatory risk disclosure. These observed variations in these variables reflect the different environmental factors in the two countries, which may affect firms' decisions over whether to reveal or withhold information about their risk. ${ }^{6}$

Our findings are consistent with the prior literature on cross-country differences, both in general disclosure practices (Cooke \& Wallace, 1990; Ball, Kothari, \& Ashok, 2000; Nobes \& Parker, 2010) and in terms of risk disclosure in particular (Dobler, Lajili, \& Zéghal, 2011). Such differences can be interpreted in light of the underlying institutional background of these two countries, which reflects the contradictory cultures that exist in Europe and their economic and regulatory milieus (La Porta, Lopez-de-Silanes, Shleifer, \& Vishny, 1998; Nobes, 1998; Moscariello, Skerratt, \& Pizzo, 2014).

\section{Insert Table 1 about here}

Panels A and B of Table 2 provide the correlation matrices for the UK and Italy, respectively. The correlation coefficients between the mandatory and voluntary risk disclosure scores in each country indicate that firms with a higher propensity to comply with the risk regulations (reflected by the mandatory score) are also likely to provide higher levels of voluntary risk disclosure than other firms. This result also suggests that firms tend to maximize (positive associations, as in Dye, 1986) rather than optimize (negative associations, as in Dye, 1990) their levels of risk disclosure for both mandatory and voluntary forms of disclosure. Specifically, this positive association between mandatory and voluntary risk disclosure supports the view that firms are likely to use the two forms of disclosure in a complementary fashion rather than as substitutes for each other, as 
This is the peer reviewed version of the following article: Corporate Governance: An International Review, which has been published in final form at http://onlinelibrary.wiley.com/doi/10.1111/corg.12095/abstract]. This article may be used for non-commercial purposes in accordance with Wiley Terms and Conditions for Self-Archiving.

has been suggested by some of the prior literature (e.g., Marshall \& Weetman, 2002; Elshandidy, Fraser, \& Hussainey, 2013). The correlation matrix also suggests that both the mandatory and voluntary risk disclosure scores are more significantly associated with most of the independent and control variables in the UK than in Italy. ${ }^{7}$

Insert Table 2 about here

\section{Empirical Model}

The impact of corporate governance factors on risk disclosure practices. We used fixed (Eq. 1) and random (Eq. 2) effects models to regress the corporate governance variables, controlling for the six firm characteristics, on the risk disclosure scores (both mandatory and voluntary scores, in separate regressions).

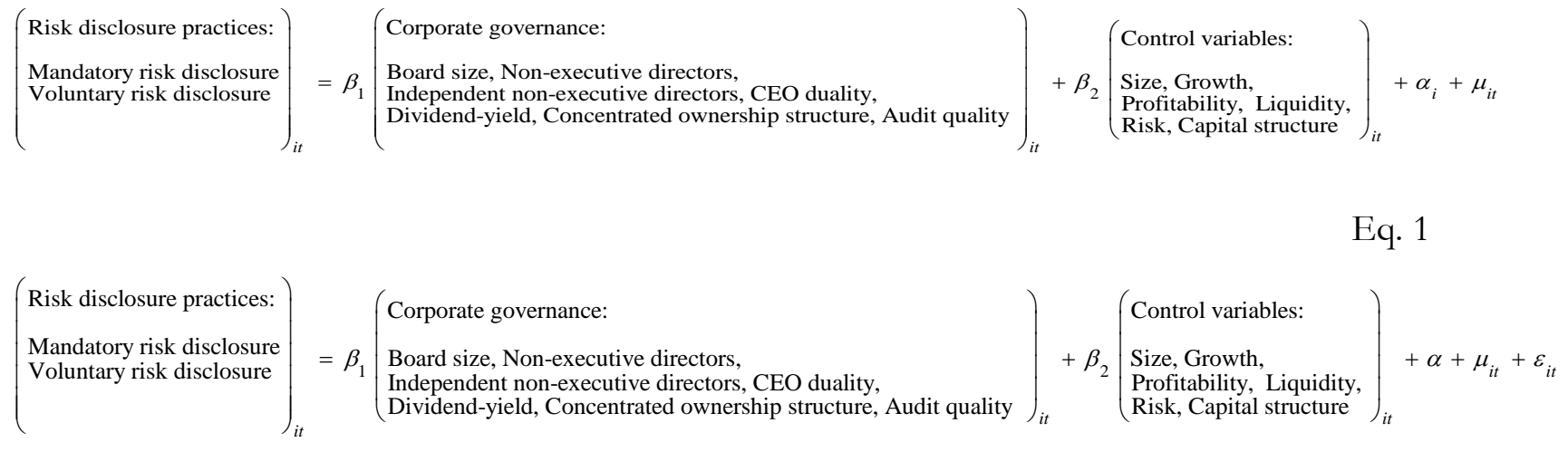

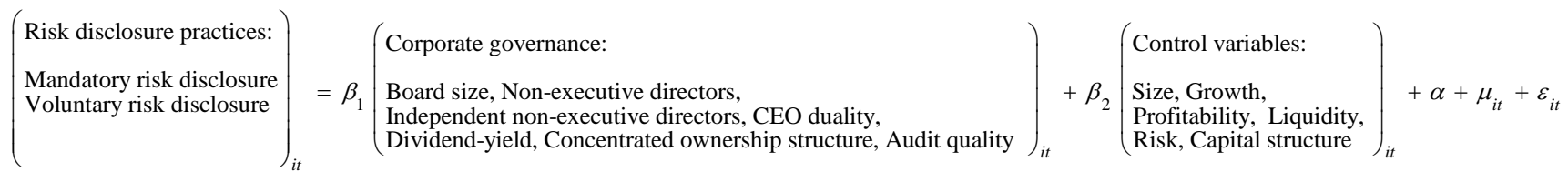

Eq. 2

Eq. 1 shows the fixed effects model that accounts for any changes in risk disclosure as a result of changes in corporate governance over the five-year period. Additionally, the model accounts for any bias in risk disclosure caused by firm and/or industry-specific effects. The fixed effects model eliminates the effects of time-invariant characteristics from the regressor variables. $\beta_{1}$ and $\beta_{2}$ are the slopes for the corporate governance and control variables, respectively. $a_{i}$ is the intercept for firm $i$, while $\mu_{i t}$ is the error term for firm $i$ in year $t$.

Eq. 2 shows the random effects model that accounts for the bias in risk disclosure caused by random variations across firms, in the UK and in Italy and across industries, over the five-year period under analysis. All variables are the same as in Eq. 1. Additionally, the error term is 
This is the peer reviewed version of the following article: Corporate Governance: An International Review, which has been published in final form at http://onlinelibrary.wiley.com/doi/10.1111/corg.12095/abstract]. This article may be used for non-commercial purposes in accordance with Wiley Terms and Conditions for Self-Archiving.

broadened from $\mu_{i}$, which captures the between-firm error, to include $\varepsilon_{i t}$, which captures the within-firm error.

The impact of risk disclosure practices on market liquidity. To observe whether risk disclosure practices are useful or not, we also examined the extent to which mandatory and voluntary risk disclosure influence a firm's market liquidity. To that end, similarly to Kravet and Muslu (2013) and Campbell et al. (2014), we used the ordinary least squares (OLS) approach, controlling for both industry and year fixed effects, and also correcting the standard error for any heteroskedastic bias. ${ }^{8}$

$$
(\text { Market liquidity })_{i t+1}=\beta_{1}\left(\begin{array}{l}
\text { Risk disclosure practices: } \\
\text { Voluntary risk disclosure } \\
\text { Mandatoy risk disclosure }
\end{array}\right)_{i t}+\beta_{2}\left(\begin{array}{l}
\text { Control variables: } \\
\text { Board size, Non-executive directors, } \\
\text { Independent non-executive directors, CEO duality, } \\
\text { BTM, Risk, Share price volatility, } \\
\text { Trading volume, Size, Liquidity, Capital structure }
\end{array}\right)_{\text {it }}
$$

In Eq. 3 market liquidity is measured as the average of the relative spreads over a three-month period, from the beginning of May to the end of July, the time period having been chosen because it is four months after fiscal year end for the reasons stated earlier. In the specification, we thus excluded all firms whose fiscal year end was different from 31 December, that is 57(2) firms, from our UK (Italian) list. All other variables remained the same as those in Eq. 1 and Eq. 2. We also used the BTM ratio, the share price volatility and the trading volume, as control variables.

\section{EMPIRICAL RESULTS}

\section{The Impact of Corporate Governance Factors on Risk Disclosure Practices}

Voluntary risk disclosure. Model 1 in Table 3 shows the results for the UK firms' voluntary risk disclosure scores. They show that large boards of directors and high proportions of non-executive directors lead to the provision of more voluntary risk information (the $t$-statistics 2.751 and 4.301 at the $1 \%$ level, respectively). These results are consistent with our expectation based on agency theory and the prior empirical research (e.g., Abraham \& Cox, 2007). As suggested by agency theory, a higher proportion of non-executive directors mitigates the conflict between 
This is the peer reviewed version of the following article: Corporate Governance: An International Review, which has been published in final form at http://onlinelibrary.wiley.com/doi/10.1111/corg.12095/abstract]. This article may be used for non-commercial purposes in accordance with Wiley Terms and Conditions for Self-Archiving.

the managers and owners by increasing transparency (see e.g., Donnelly \& Mulcahy, 2008), thus leading to a decrease in the information asymmetry between the management and the shareholders and also in the cost of monitoring.

Model 1 of Table 3 also suggests that the dividend policies of UK firms have a significant impact on the amount of risk information these firms provide voluntarily; firms with lower dividend yields are likely to provide significantly higher levels of voluntary risk disclosure than other firms (t-statistic -2.792 at 1\%). This result is consistent with the prior research (e.g., Hussainey \& Walker, 2009). The findings support our hypotheses 1, 2a and 4.

These results are also consistent with the ICAEW (1997, 1999a, 2002) ${ }^{9}$, which argues that a board of directors can integrate information taken from their internal reports regarding risk, including information about risk types and risk management, with other information found in external reports. The results can also be interpreted as relating to the UK's general expectation for good corporate governance and a high level of investor protection (e.g., La Porta, Lopez-deSilanes, Shleifer, \& Vishny, 2000, 2002). Directors are expected to play a fundamental role in mitigating the conflict between management and stakeholder aims by increasing the level of transparency, which as mentioned helps to reduce information asymmetry and agency costs. In general terms, good corporate governance can play an effective role in reallocating risk information between insiders (management) and outsiders (shareholders), which may help to achieve a fairer distribution of welfare for market participants.

In terms of our control variables in the same model, the results show, in line with prior literature such as Elshandidy, Fraser, and Hussainey (2013), that bigger firms are likely to provide significantly more voluntary risk information. This is likely because such firms are better able to prepare and integrate information for their investors, including risk information.

In summary, the above results collectively indicate that corporate governance mechanisms mostly dominate firm characteristics in explaining why UK firms voluntarily disclose risk information in their annual report narratives. 
This is the peer reviewed version of the following article: Corporate Governance: An International Review, which has been published in final form at http://onlinelibrary.wiley.com/doi/10.1111/corg.12095/abstract]. This article may be used for non-commercial purposes in accordance with Wiley Terms and Conditions for Self-Archiving.

\section{Insert Table 3 about here}

For Italy, we relied on the random effects model in lieu of the fixed effects model, since the Hausman test confirmed the null hypothesis that the error term did not correlate with the regressors. Model 2 of Table 3 suggests that corporate governance does not stimulate Italian firms to voluntarily provide risk information in their narratives. This result suggests that, notwithstanding the differences in the corporate governance variables across Italian industries as reported under footnote 6 (which were based on the one-way analysis of variance; ANOVA), these differences appear not to be statistically associated with the levels of voluntary risk disclosure. These results, therefore, do not support any of our hypotheses.

Turning to the control variables or firm characteristics, we find that Italian firms with lower levels of liquidity are likely to provide significantly higher levels of voluntary risk disclosure ( $t$ statistic -3.273 at the $1 \%$ level). This result is in line with Marshall and Weetman's (2007) and Elshandidy, Fraser, and Hussainey's (2013) theoretical arguments suggesting that firms with higher levels of liquidity risk are likely to provide more risk information to their investors than other firms.

Therefore, firm characteristics (incentives) have a higher impact than corporate governance (regulations) on the amount of voluntary risk information provided to the Italian stock market. Our conclusion here is in line with Dobler's (2008) argument, which emphasizes the importance of studying the incentives that motivate firms to provide risk information in their narratives. We might also interpret this result as demonstrating that the corporate governance environment in Italy has not developed to a level sufficient to encourage Italian firms to voluntarily provide more risk information, since doing so does not reduce agency costs. This result emphasizes the limited role currently played by corporate governance in Italy in stimulating managers to provide more meaningful information about their risk processes. In turn, this result may also suggest that further steps should be taken by the Italian regulators to improve the corporate governance mechanisms in the country. 
This is the peer reviewed version of the following article: Corporate Governance: An International Review, which has been published in final form at http://onlinelibrary.wiley.com/doi/10.1111/corg.12095/abstract]. This article may be used for non-commercial purposes in accordance with Wiley Terms and Conditions for Self-Archiving.

Mandatory risk disclosure. For the UK, Model 3 of Table 3 shows that the coefficient for audit quality is negative ( $t$-statistic -2.058 at the $5 \%$ level). This result suggests that firms whose annual reports are audited by an auditor other than one of the "big four" are likely to convey significantly more mandatory risk information than other firms. It appears that smaller auditors are likely to pay greater attention to the risk regulations than larger auditors, probably to avoid the costs of non-compliance. This result, however, does appear to be consistent with Campbell et al.'s (2014) argument that hiring one of the "big four" is likely to be associated with high audit quality and, therefore, less exposure to risk and uncertainty. Based on that argument, UK firms' motivation to reveal more risk information is likely to be high due to the increased risk and uncertainty likely to be associated with a non-"big four" auditor.

Table 3 also indicates that firms with lower growth, those that are less profitable, and those that are more risky ( $t$-statistics $-1.780,-1.918$ and -1.675 , respectively, at the $10 \%$ level) are likely to exhibit higher levels of mandatory risk disclosure than other firms, likely because they want to reassure their investors of their ability to generate potential market opportunities and to provide more details on how they manage their risks (e.g., Deumes \& Knechel, 2008; Hussainey \& Walker, 2009; Elshandidy, Fraser, \& Husssainey, 2013). Within the UK, our conclusions suggest that, similarly to the case of Italy's voluntary risk disclosure, the incentive seems to dominate the role of corporate governance in motivating firms to comply with the risk disclosure regulations.

For Italy, as shown in Model 4 of Table 3, the amount of mandatory risk information disclosed is likely to be influenced significantly by board size, the proportion of non-executive directors, and audit quality ( $t$-statistics 1.886 , at the $10 \%$ level, and 2.843 and -2.827 , at the $1 \%$ level, respectively). Another board characteristic, that of the combined role of chairman and CEO, also leads firms to comply more strongly with the risk regulations ( $t$-statistic 3.289 at the $1 \%$ level). While this result is inconsistent with agency theory, according to which the combining of these roles signals a high probability that the chairman/CEO will act in his or her own self-interest rather than in the shareholders' interests, it is consistent with other arguments suggesting that duality may 
This is the peer reviewed version of the following article: Corporate Governance: An International Review, which has been published in final form at http://onlinelibrary.wiley.com/doi/10.1111/corg.12095/abstract]. This article may be used for non-commercial purposes in accordance with Wiley Terms and Conditions for Self-Archiving.

have some benefits (e.g., Brickley, Coles, \& Jarrell, 1997), although the latter's evidence suggests that the costs of separation are generally larger than its benefits. The benefits posited include being in a good position to make relevant and timely decisions. It seems, according to our findings, that corporate governance motivates the managers of Italian firms to comply well with risk regulations. These results support hypotheses $1,2 \mathrm{a}, 3$, and 6 .

Looking at the control variables, bigger, less liquid and more risky firms are likely to exhibit higher levels of compliance with the Italian risk regulations than other firms. These three results are very similar to some of our results discussed earlier. ${ }^{10}$

Additional tests for good governance. The private information that managers have about an entity leads to the issue of moral hazard (Bushman \& Smith, 2001). Managers favor using private information for their own ends by choosing what they will disclose to market participants and regulators (Chen \& Jaggi, 2000). Since it may not be possible for market participants to observe the management's actions and credibility directly, they may have to assess the quality of a firm's risk reporting on the basis of the mechanisms of corporate governance that are in place, and the management and monitoring of those mechanisms.

It has long been held that healthy corporate governance refers to a positive process of risk management (e.g., ICAEW, 1999a). Effective risk management and supply management using high-quality data and tools are required to predict risks and reduce (unintentional) errors to a minimum. One of the many empirical papers that has examined the role of corporate governance (Brown \& Caylor, 2006) examines the relationships between corporate governance, firm valuation and firm risk. The authors conclude that firms with poor governance have lower valuations, higher risk and a higher degree of stock price volatility.

As some of the prior research (e.g., Hoitash, Hoitash, \& Bedard, 2009) suggests, strong governance can be indicated by board independence. Thus, we classify firms into strong and weak governance groups, depending on whether the proportion of independent non-executive directors is greater or less than the median. 
This is the peer reviewed version of the following article: Corporate Governance: An International Review, which has been published in final form at http://onlinelibrary.wiley.com/doi/10.1111/corg.12095/abstract]. This article may be used for non-commercial purposes in accordance with Wiley Terms and Conditions for Self-Archiving.

The fixed effects estimations shown as Model 1 of Table 4 suggest that strongly governed UK firms are likely to provide significantly high levels of risk information voluntarily in their annual report narratives. Meanwhile, only audit quality and firm size significantly influence weakly governed firms' voluntary risk disclosure, as shown in Model 5. According to the same comparison for Italian firms, we can observe that strongly (weakly) governed firms, shown under Model 2 (6) using random effects estimations, are likely to exhibit voluntary risk disclosure as a response to their liquidity (growth) incentives rather than as a response to governance factors, with the exception of the dividend yield for weakly governed firms. Model 4 of Table 4 shows that, for Italy, compliance with Italian risk regulations is highly influenced by governance factors (i.e., board size, CEO duality, and audit quality) rather than by incentives (with the exception of liquidity). In the UK, on the contrary, as shown by Models 3 and 7 of Table 4, compliance with risk regulations is likely to be influenced more by incentives than by governance.

To sum up, the main conclusions drawn based on Table 3 indicate that governance (incentives) factors influence UK firms' decision to reveal or conceal voluntary (mandatory) risk information. Contrary to those findings, incentive (governance) factors influence Italian firms' decision to reveal voluntary (mandatory) information in the narrative sections of their annual reports. Distinguishing between firms with strong and weak governance, as shown in Table 4, our findings appear to be driven mostly by strongly governed firms, in terms of the factors that affect mandatory and voluntary risk disclosure in both the UK and Italy.

\section{Insert Table 4 about here}

\section{The Impact of Risk Disclosure Practices on Market Liquidity}

Models 1 and 2 of Table 5, which exhibit standardized coefficients on all explanatory variables so as to compare the effect of mandatory and voluntary risk disclosure on market liquidity within and between the UK and Italy, show that, for UK firms, providing more risk information, whether voluntarily or mandatorily, increases their market liquidity, as observed by the relative bid-ask 
This is the peer reviewed version of the following article: Corporate Governance: An International Review, which has been published in final form at http://onlinelibrary.wiley.com/doi/10.1111/corg.12095/abstract]. This article may be used for non-commercial purposes in accordance with Wiley Terms and Conditions for Self-Archiving.

spread ( $t$-statistics -5.995 and -4.546 at the $1 \%$ level). Investors in those firms that provide high levels of risk information either voluntarily or mandatorily are likely to be more confident of a stock transaction occurring at its fairest price, which will increase the stock liquidity of those firms. Among all UK firms, as shown in Models 1 and 2, voluntary risk disclosure is likely to be 53\% ([1$0.196 / 0.128]^{* 100}$ ) more effective than mandatory risk disclosure in influencing the market liquidity.

Our results suggest that firms will have high incentives to disclose more information so as to better inform their investors; by eliminating the information asymmetry problem, this will decrease agency costs by aligning any conflicts of interests that may exist between different parties. Our results are consistent with the theoretical research, which argues that the disclosure of a large amount of information is likely to reduce the information asymmetries between non-informed or less informed investors and informed investors (e.g., Diamond \& Verrecchia, 1991). Our result is also consistent with the recent empirical evidence on risk disclosure presented in Miihkinen (2013) and Campbell et al. (2014).

While Model 3 of Table 5 indicates that voluntary risk disclosure is likely to significantly $(t-$ statistic 2.261) increase market liquidity, Model 4 of the same table indicates that mandatory risk disclosure does not affect market liquidity. Italian firms, as was shown in Table 1, are likely to provide more risk information voluntarily than they do mandatorily, as a response to those firms' managers' incentives, as was shown in Table 3 and then confirmed in Table 4. Our results shown in Table 5 (Models 3 and 4) suggest that investors in the Italian market are more likely to be incorporating the voluntary than the mandatory disclosure information, which tends to be more generic or less informative, into their stock price decisions. These results confirm those in recent empirical research on general disclosure; for instance, Cheung, Jiang, and Tan (2010) find that voluntary rather than mandatory disclosure information is likely to influence market valuations. Our result also confirms Miihkinen's (2012) argument that, in some contexts, additional 
This is the peer reviewed version of the following article: Corporate Governance: An International Review, which has been published in final form at http://onlinelibrary.wiley.com/doi/10.1111/corg.12095/abstract]. This article may be used for non-commercial purposes in accordance with Wiley Terms and Conditions for Self-Archiving.

regulations on risk disclosure might turn such disclosure into a boilerplate format, since most of the information will be irrelevant to investors.

Given that Italian firms tend to complain more about risk regulations than UK firms, as shown in Table 1, such disclosure is likely to be vague and more generic. The Italian firms appear to fill out forms that do not convey particularly useful information to investors. These firms may also fear investors' responses, especially if they feel that the latter will perceive more risk information as a bad signal. ${ }^{11}$

\section{Insert Table 5 about here}

When we distinguish between strongly and weakly governed firms in both countries, we find that, in the UK, both strongly (Models 5 and 6) and weakly (Models 9 and 10) governed firms are likely to provide useful risk information ( $t$-statistics $5.408,3.548,3.103$ and 3.313 , all at the $1 \%$ level). However, Italian firms with strong governance (Models 7 and 8) tend to provide more informative voluntary and less informative mandatory risk disclosure. Weakly governed Italian firms (Models 11 and 12) do not provide significantly useful risk information either voluntarily or mandatorily.

Comparing the standardized coefficients on mandatory and voluntary risk disclosure across strongly and weakly governed firms in both countries, it is notable that our results for all firms are driven mostly by the strongly governed firms. For example, in Models 11 and 12 weakly governed firms are shown to be more likely to provide generic or boilerplate information, while strongly governed firms are likely to provide more risk-specific information. The latter will reduce the information asymmetry between the market participants, as evidenced through the bid-ask spread. For the UK, it appears that the significant impact of voluntary risk disclosure on liquidity is likely to be more pronounced among strongly than weakly governed firms, as the impact of voluntary risk disclosure is $30 \%$ more $(0.225 / 0.174)$ effective for strongly than weakly governed firms. These results support hypothesis 7 . 
This is the peer reviewed version of the following article: Corporate Governance: An International Review, which has been published in final form at http://onlinelibrary.wiley.com/doi/10.1111/corg.12095/abstract]. This article may be used for non-commercial purposes in accordance with Wiley Terms and Conditions for Self-Archiving.

Our results have both theoretical and practical implications. First, they show that the quality of corporate governance is an important factor to consider when studying the impact of risk disclosure on market liquidity. Our main conclusions under Models 1, 2, 3 and 4 are mostly driven by firms that have strong governance (as shown in Models 5, 6, 7 and 8). Second, our results further confirm the importance of improving corporate governance factors in Italy so as to stimulate firms to provide more meaningful risk information.

\section{Robustness Checks}

Without making any distinction between voluntary and mandatory risk disclosure, Table 6 Panel A shows the factors that motivate UK and Italian firms to provide risk disclosure in general, and how those factors work among strongly and weakly governed firms. Panel B of the same table explains the impact of such aggregate disclosure on market liquidity for all, strongly governed, and weakly governed firms. Generally, we find that the aggregate risk disclosure drivers in the UK (Italy) are likely to be consistent with those associated with voluntary (mandatory) rather than mandatory (voluntary) risk disclosure, which were shown in Table 3. These results confirm our argument that it is quite difficult to draw general conclusions in terms of the incentives for mandatory and/or voluntary risk disclosure based on aggregate risk disclosure since the two types of disclosure have different drivers.

The results shown in Panel B of Table 6 suggest that in all (Model 1), strongly governed (Model 3) and weakly governed (Model 5) UK firms, aggregate risk disclosure is likely to significantly increase market liquidity by reducing information asymmetry. In the same panel, the results for Italian firms show a significant impact of aggregate risk disclosure for all firms, for strongly governed firms, but not for weakly governed firms.

\section{Insert Table 6 about here}

To observe how both UK and Italian firms behaved during the recent financial crisis, the period under analysis was divided into three: prior to the crisis (years 2005, 2006 and 2007), during 
This is the peer reviewed version of the following article: Corporate Governance: An International Review, which has been published in final form at http://onlinelibrary.wiley.com/doi/10.1111/corg.12095/abstract]. This article may be used for non-commercial purposes in accordance with Wiley Terms and Conditions for Self-Archiving.

the crisis (2008) and after the crisis (2009). Each was introduced as a dummy variable. Models 1 and 3 of Table 7 explain that, while UK firms were likely to exhibit significantly more risk information voluntarily both during and after the crisis relative to prior to the crisis, the effect of the crisis on mandated risk information was only statistically apparent during the crisis. However, Models 2 and 4 document that the financial crisis caused Italian firms to comply significantly more with the risk regulations and reveal significantly more risk information voluntarily both during and after the crisis than those firms had tended to exhibit prior to the crisis. These results are consistent with the most recent literature on risk reporting (e.g., Elshandidy, Fraser, \& Hussainey, 2014; Miihkinen, 2013), which finds that the investors' risk information needs are higher during and after the crisis.

\section{Insert Table 7 about here}

We also checked the issue of endogeneity since it has been argued to be a common problem in corporate governance research (e.g., Larcker, Richardson, \& Tuna, 2007). Using fixed effects models is seen as one method of dealing with the problem of endogeneity, as it eliminates the influence of time-invariant unobservable variables (e.g., Brown, Beekes, \& Verhoeven, 2011). As a result of our use of the fixed effects model, the remaining associations cannot be attributed to any endogeneity related to our dataset. We also implemented instrumental variables as this is the most common approach used for detecting and mitigating an endogeneity problem (e.g., Larcker, Richardson, \& Tuna, 2007). Accordingly, we extended our models by performing a lag analysis (Hoitash, Hoitash, \& Bedard, 2009), regressing the current year's mandatory and voluntary risk disclosure scores on the previous year's board characteristics, ownership structure, dividend policy and audit quality.

To validate the composition of the sub-sample used for the lag analysis, we first tested whether our previous voluntary and mandatory risk disclosure results using contemporaneous governance variables held true in the lagged case. We found similar results in the lagged case to those reported in Table 3. Further, we estimated the model using the lagged governance variables 
This is the peer reviewed version of the following article: Corporate Governance: An International Review, which has been published in final form at http://onlinelibrary.wiley.com/doi/10.1111/corg.12095/abstract]. This article may be used for non-commercial purposes in accordance with Wiley Terms and Conditions for Self-Archiving.

after distinguishing between strongly and weakly governed firms. Consistent with the Table 4 results, this analysis provides evidence that stronger corporate governance does lead to more effective risk disclosure.

We also validated our disclosure scores by changing the unit of analysis to the number of words (as in Miihkinen, 2012 and in Campbell et al., 2014) instead of the number of sentences (as used in our main analysis and in Kravet \& Muslu, 2013) for the year 2008. The new variables are dependent variables when examining the impact of corporate governance and independent variables when examining their impact on market liquidity. The results, omitted for brevity, supported our main conclusions drawn from Tables 3 and 5.

\section{CONCLUSION}

This paper examines how corporate governance influences risk disclosure practices for nonfinancial firms in the UK and Italy over a five-year period. Our findings support the significant role of corporate governance in motivating UK firms to exhibit higher levels of voluntary than mandatory risk disclosure in the narrative sections of their annual reports. In contrast, our findings show that corporate governance motivates Italian firms to provide more risk information mandatorily than voluntarily, likely due to the incentives of firms' managers regarding the inclusion of voluntary risk information in their narratives, confirming Melis's (2000) findings on the Italian corporate governance system. Drawing a distinction between strongly and weakly governed firms shows that our findings regarding those factors that affect voluntary and mandatory risk disclosure appear to be driven more by strongly governed firms, in both countries.

This paper also investigates the impact of risk disclosure practices on market liquidity. We find that UK firms are likely to reveal meaningful risk information, which describes a firm's specific conditions and leads investors to better incorporate the information into their price decisions. This in turn improves market liquidity as information asymmetry decreases. We draw the same conclusion for both strong and weak corporate governance firms in the UK. In Italy, we find that 
This is the peer reviewed version of the following article: Corporate Governance: An International Review, which has been published in final form at http://onlinelibrary.wiley.com/doi/10.1111/corg.12095/abstract]. This article may be used for non-commercial purposes in accordance with Wiley Terms and Conditions for Self-Archiving.

voluntary rather than mandatory risk disclosure significantly improves market liquidity. This conclusion could be reached for strongly but not for weakly governed firms. Our results suggest that, while voluntary risk disclosure seems to be informative to investors, mandatory risk disclosure is seen as generic or boilerplate.

Our results have several implications for regulators and investors in both the UK and Italy. They support the UK's regulatory trend regarding risk disclosure, which emphasizes directors' role in facilitating the process of revealing more risk information and the encouragement rather than mandating of risk disclosure. However, the results signal a need for further improvements in the Italian context. Our findings rationalize the debate over the impact improved corporate governance has on disclosure practices, in general, and within the Italian context in particular. The logic of this rationalization may lead policymakers to encourage firms to implement corporate governance so as to improve the informational content of their financial reporting.

Investors may also find these results useful, since they provide empirical evidence that corporate governance attributes (e.g., board size, executive directors) do influence managers differently in terms of the risk information they reveal. Investors, therefore, might do well to rely on such attributes (e.g., a large board size and a high proportion of non-executive directors) to form their own expectations about the risk information that is revealed, either voluntarily and/or mandatorily. Our findings support the view that disclosing risk information in the narrative sections of annual reports is seen as more credible in the UK than in Italy, as such information is likely to be more closely related to investors' price decisions in the UK than in Italy.

Our analyses are limited by the following details: (1) including more countries when investigating the impact of corporate governance on risk disclosure practices would allow country characteristics to be included; thus, future research could observe how these variables empirically explain the variation in risk disclosure practices across different countries; (2) looking at the quality rather than the quantity of risk disclosure in further investigations will allow researchers to observe whether there are differences between the results driven by quantity- versus quality-based research 
This is the peer reviewed version of the following article: Corporate Governance: An International Review, which has been published in final form at http://onlinelibrary.wiley.com/doi/10.1111/corg.12095/abstract]. This article may be used for non-commercial purposes in accordance with Wiley Terms and Conditions for Self-Archiving.

when measuring disclosure generally (e.g., Beattie, McInnes, \& Fearnley, 2004) and risk disclosure in particular (e.g., Beretta \& Bozzolan, 2004; Miihkinen, 2012); (3) looking at other outlets of corporate communication (e.g., Li, 2010b), such as online resources, conference calls and/or financial analysts' reports, might be an avenue for future research, helping to answer questions such as how governance affects risk disclosure through different outlets and whether certain governance characteristics are more strongly associated with some outlets than others.

\section{NOTES}

\footnotetext{
${ }^{1}$ Notably, the Companies Act 2006 identifies certain requirements regarding directors' duties (e.g., enhancing shareholder value), shareholders' rights (e.g., voting, pre-emption rights) and disclosure requirements (e.g., directors' remuneration).

2 The EU's Transparency Directive of 2004 (Directive 2004/109/EC) stated that only public companies should include information about the principal risks and uncertainties they might face in their interim management report (Article 5 (4)).

3 In 2010 the IASB issued the IFRS practice statement, Management Commentary, which contained some requirements regarding risk disclosure. Those requirements do not affect our paper since the effective date of this non-mandatory statement is later than the end of our sample period. The statement maintained (IASB, 2010:13) that "management should disclose its principal strategic, commercial, operational and financial risks, which are those that may significantly affect the entity's strategies and progress of the entity's value. The description of the principal risks facing the entity should cover both exposures to negative consequences and potential opportunities. Management commentary provides useful information when it discusses the principal risks and uncertainties necessary to understand management's objectives and strategies for the entity".

${ }^{4}$ It is worthy of mentioning that we have relied on the same logic as ICAEW (1997, Section 3, p.p. 16-26 and 2011 , appendix 1, p.p. 47-49) when analyzing the accounting standards related to risk disclosure. Furthermore, and consistent with Elshandidy, Fraser, and Hussainey (2013) and Kravet and Muslu (2013), our decision on whether or not a word should be included in our final risk word list was based on the following: it had to appear at least once in an initial textual search of 30 annual reports in each country that were selected randomly from the year 2007.

${ }^{5}$ Our main descriptive statistics for the voluntary and mandatory risk disclosure scores based on automated and manual content analysis for each country indicate that, on average, the manual and automated disclosure scores were similar. However, the manual disclosure scores were less homogeneous, as indicated by the standard deviation.

${ }^{6}$ Our results based on ANOVA analysis, not reported, showed that, even within each country, firms were likely to differ in their risk disclosure policies between years (longitudinally) and across different industries. Those industries were basic materials, consumer goods, consumer services, health care, industrials, technology, telecommunication and utilities. The result shows the importance of considering the influence of industry (e.g., Beretta \& Bozzolan, 2004) when examining risk disclosure levels. These unreported results are available upon request from the corresponding (principal) author.

${ }^{7}$ Examining each of these pairs of correlation coefficients confirms that multicollinearity is unlikely to exist with these variables, as the majority of the coefficients are relatively low. The only exception to this rule is the correlation between the two risk disclosure scores, especially in the case of the UK firms. We further calculated the variance inflation
} 
factors (VIFs), and found that all values were less than 3. Thus, we concluded that multicollinearity does not pose a problem for our regression model.

${ }^{8}$ We assessed whether panel regression was the best way to estimate how risk disclosure influences market liquidity, using the Breusch-Pagan Lagrange multiplier, which produced a small chi-squared value, indicating a failure to reject the null hypothesis of no panel effects and suggesting that OLS would be preferable (Wooldridge, 2010).

${ }^{9}$ The ICAEW (2002:9) states that "directors should communicate clearly what actions they are taking to manage these risks, providing sufficient information to allow investors to make a judgement about the risks being undertaken by the company".

10 The significance of the association between mandatory or voluntary risk disclosure and non-executive or independent non-executive directors varies from the correlation matrix (Table 2) to the regression models (Table 3). This could be because the correlation matrix, as a bivariate analysis method, gives just the significance of the association between each pair of variables (i.e., mandatory or voluntary and one factor of corporate governance such as non-executive directors) in isolation of any potential impact of other corporate governance factors. Meanwhile, in multiple regression analysis, as a multivariate analysis method, the associations between either mandatory or voluntary risk disclosure and the combination of all the explanatory variables (i.e., including non-executive directors and independent non-executive directors) are observed simultaneously. Thus, the significances of the impacts of board characteristics on risk disclosure practices are subject to whether we are considering those characteristics individually or combined.

${ }^{11}$ In further tests, we ran all of our analyses combining both voluntary and mandatory risk disclosure for two reasons: to control for the voluntary (mandatory) while observing the impact of mandatory (voluntary) risk disclosure on market liquidity, and because a firm might choose to engage with both forms of disclosure. Our unreported results, available upon request from the corresponding (principal) author, suggest that UK and Italian firms tend to disclose firm-specific information through voluntary rather than mandatory risk disclosure, which is what affects the investors' price decisions that can then improve market liquidity. Our conclusion, based on all firms, is likely to be driven more by strongly than weakly governed firms.

\section{REFERENCES}

Abraham, S. \& Cox, P. 2007. Analysing the determinants of narrative risk information in UK FTSE 100 annual reports. The British Accounting Review, 39(3): 227-248.

Ajinkya, B., Bhojraj, S. \& Sengupta, P. 2005. The association between outside directors, institutional investors and the properties of management earnings forecasts. Journal of Accounting Research, 43(3): 343-376.

Allegrini, M. \& Greco, G. 2013. Corporate boards, audit committees and voluntary disclosure: Evidence from Italian listed companies. Journal of Management and Governance, 17(1): 187-216.

ASB 1993. The Operating and financial review. London: Accounting Standards Board.

Bagnoli, M. \& Watts, S. G. 2007. Financial Reporting and supplemental voluntary disclosures. Journal of Accounting Research, 45(5): 885-913.

Ball, R., Kothari, S. P. \& Ashok, R. 2000. The effect of international institutional factors on properties of accounting earnings. Journal of Accounting and Economics, 29(1): 1-51.

Barako, D. G., Hancock, P. \& Izan, H. Y. 2006. Factors influencing voluntary corporate disclosure by Kenyan companies. Corporate Governance: An International Review, 14(2): 107125.

Beattie, V., McInnes, B. \& Fearnley, S. 2004. A methodology for analysing and evaluating narratives in annual reports: A comprehensive descriptive profile and metrics for disclosure quality attributes. Accounting Forum, 28(3): 205-236.

Beretta, S. \& Bozzolan, S. 2004. A framework for the analysis of firm risk communication. The International Journal of Accounting, 39(3): 265-288.

Borsa Italiana 2014. Codice di autodisciplina. Roma: Comitato per la Corporate Governance.

Botosan, C. A. 1997. Disclosure level and the cost of equity capital. The Accounting Review, 72(3): 323-349.

Bowman, E. H. 1984. Content analysis of annual reports for corporate strategy and risk. Interfaces, 14(1): 61-71.

Brammer, S. \& Pavelin, S. 2006. Voluntary environmental disclosures by large UK companies. Journal of Business Finance and Accoirnting, 33(7-8): 1168-1188. 
Brickley, J. A., Coles, J. L. \& Jarrell, G. 1997. Leadership structure: separating the CEO and chairman of the board. Journal of Corporate Finance, 3(3): 189-220.

Brown, L. D. \& Caylor, M. L. 2006. Corporate governance and firm valuation. Journal of Accounting and Public Policy, 25(4): 409-434.

Brown, P., Beekes, W. \& Verhoeven, P. 2011. Corporate governance, accounting and finance: A review. Accounting and Finance, 51(1): 96-172.

Bushman, R. M. \& Smith, A. J. 2001. Financial accounting information and corporate governance. Journal of Accounting and Economics, 32(1-3): 237-333.

Butler, M., Kraft, A. \& Weiss, I. S. 2007. The effect of reporting frequency on the timeliness of earnings: The cases of voluntary and mandatory interim reports. Joumal of Accounting and Economics, 43(2-3): 181-217.

Cadbury Report 1992. Report of the Committee on the Financial Aspects of Corporate Governance. London: Committee on the Financial Aspects of Corporate Governance.

Camfferman, K. \& Cooke, T. E. 2002. An analysis of disclosure in the annual reports of U.K. and Dutch companies. Journal of International Accounting Research, 1(1): 3-30.

Campbell, J. L., Chen, H., Dhaliwal, D. S., Lu, H. \& Steele, L. B. 2014. The information content of mandatory risk factor disclosures in corporate filings. Review of Accounting Studies, 19(1), 396-455.

Cerbioni, F. \& Parbonetti, A. 2007. Exploring the effects of corporate governance on intellectual capital disclosure: An analysis of European biotechnology companies. European Accounting Review, 16(4): 791-826.

Chavent, M., Ding, Y., Fu, L., Stolowy, H. \& Wang, H. 2006. Disclosure and determinants studies: An extension using the divisive clustering method (DIV). European Accounting Review, 15(2): 181-218.

Chen, C. J. P. \& Jaggi, B. 2000. Association between independent nonexecutive directors, family control and financial disclosures in Hong Kong. Journal of Accounting and Public Policy, 19(4-5): 285-310.

Cheng, E. C. M. \& Courtenay, S. M. 2006. Board composition, regulatory regime and voluntary disclosure. The International Journal of Accounting, 41(3): 262-289.

Cheung, Y. L., Jiang, P. \& Tan, W. 2010. A transparency Disclosure Index Measuring Disclosures: Chinese Listed Companies. Journal of Accounting and Public Policy, 29(3), 259-280.

Cooke, T. E. \& Wallace, R. S. O. 1990. Financial disclosure regulation and its environment: A review and further analysis. Journal of Accounting and Public Policy, 9(2): 79-110.

Core, J. 2001. A review of the empirical disclosure literature: Discussion. Journal of Accounting and Economics, 31(1-3): 441-456.

Deumes, R. 2008. Corporate risk reporting: A content analysis of narrative risk disclosures in prospectuses. Journal of Business Communication, 45(2): 120-157.

Deumes, R. \& Knechel, W. R. 2008. Economic incentives for voluntary reporting on internal risk management and control systems. Auditing: A Journal of Practice and Theory, 27(1): 35-66.

Diamond, D. W. \& Verrecchia, R. E. 1991. Disclosure, Liquidity and the Cost of Capital. The Journal of Finance, 46(4): 1325-1359.

Di Pietra, R., Grambovas, C. A., Raonic, I. \& Riccaboni, A. 2008. The effects of board size and "busy" directors on the market value of Italian companies. Journal of Management and Governance, 12(1): 73-91.

Dobler, M. 2008. Incentives for risk reporting - a discretionary disclosure and cheap talk approach. The International Journal of Accounting, 43(2): 184-206.

Dobler, M., Lajili, K. \& Zéghal, D. 2011. Attributes of corporate risk disclosure: An international investigation in the manufacturing Sector. Journal of International Accounting Research, 10(2): 1-22. 
Donnelly, R. \& Mulcahy, M. 2008. Board structure, ownership, and voluntary disclosure in Ireland. Corporate Governance: An International Review, 16(5): 416-429.

Dye, R. A. 1986. Proprietary and nonproprietary disclosures. Journal of Business, 59(2): 331366.

Dye, R. A. 1990. Mandatory versus voluntary disclosures: the cases of financial and real externalities. The Accounting Review, 65(1): 1-24.

Einhorn, E. 2005. The nature of the interaction between mandatory and voluntary disclosures. Journal of Accounting Research, 43(4): 593-621.

Elshandidy, T., Fraser, I. \& Hussainey, K. 2013. Aggregated, voluntary, and mandatory risk disclosure incentives: Evidence from UK FTSE all-share companies. International Review of Financial Analysis, 30: 320-333.

Elshandidy, T., Fraser, I. \& Hussainey, K. 2014. What drives mandatory and voluntary risk reporting variations across Germany, UK, and US? The British Accounting Review, Forthcoming.

Eng, L. L. \& Mak, Y. T. 2003. Corporate governance and voluntary disclosure. Journal of Accounting and Public Policy, 22(4): 325-345.

Faccio, M. \& Lang, L. H. P. 2002. The ultimate ownership of Western European corporations. Joumal of Financial Economics, 65(3): 365-395.

Fama, E. \& Jensen, M. C. 1983. Separation of ownership and control. Journal of Law and Economics, 26(2): 301-326.

Farinha, J. 2003. Dividend policy, corporate governance and the managerial entrenchment hypothesis: An empirical analysis. Journal of Business Finance and Accounting, 30(910): 1173-1209.

Finkelstein, S. \& D’Aveni, R. A. 1994. CEO duality as a double-edged sword: How boards of directors balance entrenchment avoidance and unity of command. Academy of Management Journal, 37(5): 1079-1108.

Fluck, Z. 1998. Optimal financial contracting: Debt versus outside equity. Review of Financial Studies, 11(2): 383-418.

Forker, J. J. 1992. Corporate governance and disclosure quality. Accounting and Business Research, 22(86): 111-124.

Frankel, R. M., Johnson, M. F. \& Nelson, K. K. 2002. The relation between auditors fees` for non audit services and earnings management. The Accounting Review, 77(4): 71-105.

FRC 2012. The UK Corporate Governance Code. London: Financial Reporting Council.

Gaver, J. J. \& Gaver, K. J. 1993. Additional evidence on the association between the investment opportunity set and corporate financing, dividend, and compensation policies. Journal of Accounting and Economics, 16(1-3): 125-160.

Gigler, F. \& Hemmer, T. 1998. On the frequency, quality, and informational role of mandatory financial reports. Journal of Accounting Research, 36: 117-147.

Gordon, E. A., Greiner, A., Kohlbeck, M. J., Lin, S. \& Skaife, H. 2013. Challenges and opportunities in cross-country accounting research. Accounting Horizons, 27(1): 141-154.

Gul, F. A. \& Leung, S. 2004. Board leadership, outside directors' expertise and voluntary corporate disclosure. Journal of Accounting and Public Policy, 23(5): 351-379.

Hoitash, U., Hoitash, R. \& Bedard, J. C. 2009. Corporate governance and internal control over financial reporting: A comparison of regulatory regimes. The Accounting Review, 84(3): 839-867.

Hussainey, K. \& Walker, M. 2009. The effects of voluntary disclosure and dividend propensity on prices leading earnings. Accounting and Business Research, 39(1): 37-55.

IASB 2010. IFRS Practice Statement: Management Commentary. London: International Accounting Standards Board.

ICAEW 1997. Financial reporting of risks - Proposal for a statement of business risks. London: Institute of Chartered Accountants in England and Wales. 
ICAEW 1999a. No surprises: The case for better risk reporting. London: Institute of Chartered Accountants in England and Wales.

ICAEW 1999b. Internal Control: Guidance for Directors on the Combined Code. London: Institute of Chartered Accountants in England and Wales.

ICAEW 2002. Risk management for SMEs. London: Institute of Chartered Accountants in England and Wales.

ICAEW 2011. Reporting business risks: Meeting expectations. London: Institute of Chartered Accountants in England and Wales.

IRDCEC 2008. Documento n. 1. La Relazione sulla Gestione. Alcune considerazioni. Roma: Istituto di Ricerca dei Dottori Commercialisti e degli Esperti Contabili.

Jensen, M. C. 1986. Agency costs of free cash flow, corporate finance, and takeovers. American Economic Review, 76(2): 323-329.

Jorgensen, B. N. \& Kirschenheiter, M. T. 2003. Discretionary Risk Disclosures. The Accounting Review, 78(2): 449-469.

Jorgensen, B. N. \& Kirschenheiter, M. T. 2012. Interactive discretionary disclosures. Contemporary Accounting Research, 29(2): 382-397.

Jorion, P. 2002. How informative are value-at-risk disclosures? The Accounting Review, 77(4): 911-931.

Judge, W. 2011. The multiple levels of analysis involved with corporate governance studies. Corporate Governance: An International Review, 19(1): 1-2.

Kanagaretnam, K., Lobo, G. J. \& Whalen, D. J. 2007. Does good corporate governance reduce information asymmetry around quarterly earnings announcements? Journal of Accounting and Public Policy, 26(4): 497-522.

Karamanou, I. \& Vafeas, N. 2005. The association between corporate boards, audit committees and management earnings forecasts: An empirical analysis. Journal of Accounting Research, 43(3): 453-486.

Kearney, C. \& Liu, S. 2014. Textual sentiment in finance: A survey of methods and models. International Review of Financial Analysis, 33: 171-185.

Kravet, T. \& Muslu, V. 2013. Textual Risk Disclosures and Investors' Risk Perceptions. Review of Accounting Studies, 18(4), 1088-1122.

La Porta, R., Lopez-de-Silanes, F., Shleifer, A. \& Vishny, R. 1998. Law and finance. Journal of Political Economy, 106(6): 1113-1155.

La Porta, R., Lopez-de-Silanes, F., Shleifer, A. \& Vishny, R. 2000. Investor protection and corporate governance. Journal of Financial Economics, 58(1-2): 3-27.

La Porta, R., Lopez-de-Silanes, F., Shleifer, A. \& Vishny, R. 2002. Investor protection and corporate valuation. The Journal of Finance, 57(3): 1147-1170.

Larcker, D. F., Richardson, S. A. \& Tuna, A. I. 2007. Corporate governance, accounting outcomes, and organizational performance. The Accounting Review, 82(4): 963-1008.

Leuz, C. \& Verrecchia R. E. 2000. The Economic Consequences of Incresead Disclosure. Journal of Accounting Research, 38(3): 91-124.

Li, F. 2010a. The information content of forward-looking statements in corporate filings - A naïve Bayesian machine learning approach. Joumal of Accounting Research, 48(5): 1049-1102.

Li, F. 2010b. Textual analysis of corporate disclosures: A survey of the literature. Journal of Accounting Literature, 29: 143-165.

Li, J., Pike, R. \& Haniffa R. 2008. Intellectual capital disclosure and corporate governance structure in UK firms. Accounting and Business Research, 38(2): 137-159.

Lim, S., Matolcsy, Z. \& Chow, D. 2007. The association between board composition and different types of voluntary disclosure. European Accounting Review, 16(3): 555-583.

Linsley, P. M. \& Shrives, P. J. 2006. Risk reporting: A study of risk disclosures in the annual reports of UK companies. The British Accounting Review, 38(4): 387-404. 
Lynck, J. S., Netter, J. M. \& Yang, T. 2008. The determinants of board structure. Joumal of Financial Economics, 87(2): 308-328.

Mallin, C. \& Ow-Yong, K. 2012. Factors influencing corporate governance disclosures: Evidence from Alternative Investment Market (AIM) companies in the UK. The European Journal of Finance, 18(6): 515-533.

Mancinelli, L. \& Ozkan, A. 2006. Ownership structure and dividend policy: Evidence from Italian firms. The European Journal of Finance, 12(3): 265-282.

Marshall, A. P. \& Weetman, P. 2002. Information asymmetry in disclosure of foreign exchange risk management: Can regulation be effective? Joumal of Economics and Business, 54(1): 31-53.

Marshall, A. P. \& Weetman, P. 2007. Modelling transparency in disclosure: The case of foreign exchange risk management. Journal of Business Finance and Accounting, 34(5-6): 705739.

Melis, A. 2000. Corporate governance in Italy. Corporate Governance: An International Review, 8(4): 347-355.

Miihkinen, A. 2012. What Drives Quality of Firm Risk Disclosure? The Impact of National Disclosure Standard and Reporting Incentives under IFRS. The International Journal of Accounting, 47(4): 437-468.

Miihkinen, A. 2013. The Usefulness of Firm Risk Disclosures under Different Firm-Riskiness, Investor-Interest, and Market Conditions. Advances in International Accounting, 29(2): 312-331.

Moscariello, N., Skerratt, L. \& Pizzo, M. 2014. Mandatory IFRS adoption and the cost of debt in Italy and UK. Accounting and Business Research, 44(1): 63-82.

Nobes, C. W. 1998. Towards a general model of the reasons for international differences in financial reporting. Abacus, 34(2): 162-187.

Nobes, C. W. \& Parker, R. H. 2010. Comparative International Accounting. Pearson Education Limited, Harlow, Essex, U.K.

Patelli, L. \& Prencipe, A. 2007. The relationship between voluntary disclosure and independent directors in the presence of a dominant shareholder. European Accounting Review, 16(1): $5-33$.

Rajgopal, S. 1999. Early evidence on the informativeness of the SEC's market risk disclosures: The case of commodity price risk exposure of oil and gas producers. The Accounting Review, 74(3): 251-280.

Romano, G. \& Guerrini, A. 2012. Corporate governance and accounting enforcement actions in Italy. Managerial Auditing Journal, 27(7): 622-638.

Shleifer, A. \& Vishny, A. R. 1997. A survey of corporate governance. The Journal of Finance, 52(2): 737-783.

Sloan, R. G. 2001. Financial accounting and corporate governance: A discussion. Journal of Accounting and Economics, 32(1-3): 335-347.

Verrecchia, R. E. 2001. Essays on disclosure. Journal of Accounting and Economics, 32(1-3): 97-180.

Wang, M. \& Hussainey, K. 2013. Voluntary forward-looking statements driven by corporate governance and their value relevance. Journal of Accounting and Public Policy, 32(3): 26-49.

Wooldridge, J. M. 2010. Econometric Analysis of Cross Section and Panel Data. MIT Press: Cambridge, MA.

Worrell, D. L., Nemec, C. \& Davidson, W. N. 1997. One hat too many: Key executive plurality and shareholder wealth. Strategic Management Journal, 18(6): 499-507.

Yermack, D. 1996. Higher market valuation of companies with a small board of directors. Journal of Financial Economics, 40(2): 185-211. 